\title{
Efektifitas Terapi Psikoedukasi terhadap Peningkatan Tumbuh Kembang Anak
}

\author{
Ummu Muntamah $^{1}$, Siti Haryani ${ }^{2}$, Ana Puji Astuti ${ }^{3}$ \\ ${ }^{1,2,3}$ Fakultas Keperawatan, Universitas Ngudi Waluyo \\ *Email: haryanish01@gmail.com
}

\begin{abstract}
Background: The problem from this research is a nurse as part of health services to contribute in realizing from the program to improve the quality of children's development through efforts to psychological services of children. This is a nurse as a concelor.This research has purpose to describe about effectiveness of psychoeduation to development child. Methods: This type of correlation research, research methods with action research, the sampling techniques is using total sampling technique, the number of samples used all kindergarten students Nurul Izzah, statistical tests using Wilcoxon. This data has analyzed with descriptive analysis dan pre test dan post test design use SPSS (Statistical Packages for Social Sciences). Second step is implementation of psychoeducation to the parents, the instrument used is to use the KPSP question guide object of this research is children and parents. This resesarch was done 2 step. First step was done pre test of children's development use by KPSP. Results: The result is psychoeduation very strong influences on children's development $p=0.000(p<0.05)$. Conclusion: Psychoeducation therapy will help the development of children according to age. Research recommendations are to support the growth and development of children, schools can provide education and training on psychoeducation by involving teachers and parents.
\end{abstract}

Keywords: development, psychoeducation

\section{PENDAHULUAN}

Tumbuh kembang anak merupakan komponen penting untuk diperhatikan oleh orang tua, karena tumbuh kembang itu sendiri bertambahnya besar, ukuran dan bertambahnya skill atau kemampuan pada anak (Soetjjiningsih, 2014). Beberapa aspek yang terdapat pada proses saat anak mengalami fase pertumbuhan dan perkembangan merupakan salah satu hal yang harus orang tua perhatikan secara serius. Hal ini disebabkan bahwa aspek tersebut itulah yang dapat menjelaskan mengenai bagaimana anak mengalami fase pertumbuhan dan perkembangan dalam pembentukan seseorang, baik secara fisik maupun psikososial.

Banyak orang tua beranggapan dan menganggap bahwa selama anak tidak merasa sakit itu artinya anak tersebut tidak mengalami masalah pada kesehatan termasuk pertumbuhan dan perkembangannya (Setiawati, 2006).
Tahapan tumbuh kembang anak terdapat suatu masa yang disebut dengan masa kritis, sehingga sangat membutuhkan beberapa stimulasi ataupun rangsangan dengan tujuan potensi dapat berkembang sesuai dengan tingkat usia. Anak usia dini yaitu, dimana anak pada fase lima tahun pertama dalam kehidupan anak, di fase itulah merupakan masa usia anak sangat peka terhadap lingkungan yang ada disekitar anak tersebut.

Pada masa ini, tentu harus menjadi perhatian orang tua, karena masa tersebut sangat pendek dan tidak akan mungkin dapat terulang kembali. Masa inilah yang disebut dengan masa keemasan atau disebut dengan golden period. Ada juga istilah yang menyebutkan sebagai jendela kesempatan atau window of opportunity dan masa kritis atau critical period . Pada setiap kelainan ataupun penyimpangan meskipun itu sifatnya kecil, namun apabila tidak terdeksi secara dini atau bahkan tidak segera ditangani dengan 
baik, hal ini tentu dapat mengurangi kualitas sumber daya manusia kelak kemudian hari (Depkes RI, 2016).

Terdapat dua faktor yang sangat penting yang dapat mempengaruhi pertumbuhan dan perkembangan seorang anak, yaitu pertama, faktor genetik (keturunan), dan faktor yang kedua adalah faktor stimulasi lingkungan (Baraja, 2008). Stimulasi adalah suatu kegiatan yang merangsang berbagai kemampuan dasar anak sehingga anak dapat tumbuh dan berkembang secara optimal (Depkes RI, 2016). Perawat yang merupakan salah satu bagian dari pelayanan kesehatan, tentunya peran perawat harus dapat membantu mewujudkan program peningkatan kualitas perkembangan anak yaitu melalui upaya pelayanan psikologis anak. Peran perawat dalam perkembangan anak yaitu sebagai konselor (Syamsu, 2007).

Hasil penelitian Nainggolan (2019) melaporkan adanya peningkatan perkembangan sosial dan emosional anak pra sekolah pada orang tua yang mendapatkan parenting psikoedukasi. Kesimpulan penelitian tersebut yaitu ada pengaruh parenting psikoedukasi pada orang tua terhadap perkembangan emosional dan perkembangan sosial pada anak usia pra sekolah (Insiyah, 2019; Nainggolan CRT, 2019). Berdasarkan kondisi tersebut, peneliti merasa tertarik untuk melakukan penelitian dengan memberikan treatment ataupun penanganan yang dilakukan pada orang tua dengan memberikan intervensi psikoedukasi. Intervensi psikoedukasi adalah suatu intervensi yang fokus untuk mendidik partisipan yakni individu, keluarga dan kelompok, tentang tantangan dalam hidup secara signifikan. Metode ini membantu partisipan dalam mengembangkan berbagai macam sumber-sumber dukungan, sebagai contoh sumber dukungan sosial dalam menghadapi tantangan tersebut serta mengembangkan keterampilan coping untuk menghadapi tantangan tersebut (Walsh, 2010). Tujuan dari penelitian ini adalah untuk mengetahui efektifitas psikoedukasi terhadap tumbuh kembang anak.

\section{METODE PENELITIAN}

Metode penelitian adalah metode action research, dimana terdiri dari dua tahap yaitu pada tahap pertama peneliti melakukan kajian (research) pada tumbuh kembang anak melalui kuisioner pra skrining perkembangan (KPSP) oleh peneliti berdasarkan kriteria inklusi yakni anak usia 4-5 tahun, sehat dan bersedia dilakukan test. Sedangkan kriteria ekslusi adalah anak yang sakit, dan tidak bersedia dilakukan tes. Sebelumnya peneliti meminta penandatanganan inform consent pada orang tua sebagai dasar persetujuan untuk dijadikan responden.

Pada tahap kedua, peneliti melaksanakan (action) yaitu implementasi psikoedukasi dengan tujuan untuk menerapkan sekaligus untuk menguji penerapan dan efektifitas psikoedukasi yang diberikan pada orang tua terutama pada anak yang mengalami penyimpangan pada tumbuh kembangnya. Peneliti memberikan pelatihan tentang psikoedukasi, dan tumbuh kembang pada anak kepada orang tua dan guru taman kanak-kanak selama 3 kali pertemuan. Setelah 3 minggu dilakukan pelatihan dan tes KPSP, kemudian peneliti melakukan konseling pada orang tua terutama dilakukan pada anak yang mengalami keterlambatan dalam tumbuh kembangnya berdasarkan evaluasi KPSP. Evaluasi 
meliputi ketrampilan motorik halus, Sebelum dilakukan survei, dilaksanakan ketrampilan motorik kasar, bahasa, berdasarkan pedoman pertanyaan personal sosial berdasarkan KPSP.

berdasarkan metode KPSP. Data yang

Sampel pada penelitian ini adalah siswa TK A Nurul Izzah yang berjumlah 76 orang, dimana pengambilan sampel dengan metode total sampling. Metode pengumpulan data yaitu survei dengan menggunakan kuesioner terstruktur. diperoleh kemudian dianalisis dengan metode descriptive analysis dan one group pre dan post test design mengunakan wilcoxon melalui program SPSS (Statistical Packages for Social

\section{HASIL PENELITIAN}

Karakteristik responden berdasarkan usia tergambar pada tabel berikut:

Tabel 1. Tabel Distribusi Berdasarkan Karakteristik Responden

\begin{tabular}{llcc}
\hline Karakteristik Responden & Kategori & Jumlah & Persentase (\%) \\
\hline Umur (Bulan) & 48 & 5 & $6.58 \%$ \\
& 54 & 30 & $39.47 \%$ \\
& 60 & 25 & $32.89 \%$ \\
& 66 & 15 & $19.74 \%$ \\
& 72 & 1 & $1.32 \%$ \\
\hline Jenis Kelamin & Laki-laki & 38 & $50 \%$ \\
& Perempuan & 38 & $50 \%$ \\
\hline Pekerjaan Orang Tua & Buruh & 20 & $26,31 \%$ \\
& Swasta & 18 & $23,68 \%$ \\
& IRT & 38 & $50 \%$ \\
\hline Tingkat Pendidikan & SMP & 32 & $42,10 \%$ \\
& SMA & 38 & $50 \%$ \\
& PT & 6 & $7,89 \%$ \\
\hline
\end{tabular}

Sebagian besar responden yaitu anak pendidikan responden bervariasi. berusia 54-66 bulan. Komposisi laki-laki Interpretasi hasil test perkembangan dan perempuan pada penelitian ini sama. sebelum dilakukan terapi psikoedukasi Pekerjaan orang tua dan tingkat tergambar pada tabel 2 berikut :

Tabel 2. Interpretasi Hasil Test Perkembangan Sebelum dilakukan Terapi Psikoedukasi

\begin{tabular}{llcc}
\hline Test Perkembangan & Interpretasi Hasil Test & Jumlah & Persentase (\%) \\
\hline \multirow{3}{*}{ Sebelum psikoedukasi } & Sesuai (S) & 23 & $30.26 \%$ \\
& Meragukan (M) & 39 & $51.32 \%$ \\
& Penyimpangan (P) & 14 & $18.42 \%$ \\
\multirow{3}{*}{ Setelah Psikoedukasi } & Sesuai (S) & 64 & $84.21 \%$ \\
& Meragukan (M) & 11 & $14.47 \%$ \\
& Penyimpangan (P) & 1 & $1.32 \%$ \\
\hline
\end{tabular}


Berdasarkan tabel 2 sebelum dilakukan pelatihan psikoedukasi dapat dinyatakan sebagian besar perkembangan anak pada kategori meragukan adalah sebesar $51.32 \%$, sedangkan setelah dilakukan pelatihan psikoedukasi sebagian besar interpretasi hasil test perkembangan adalah sesuai (S) usia perkembangan anak yaitu sebesar 64 orang $(84.21 \%)$. Hasil analisis efektifitas terapi psikoedukasi terhadap perkembangan anak tergambar pada tabel 3:

Tabel 3. Efektifitas Terapi Psikoedukasi terhadap Perkembangan Anak

\begin{tabular}{ccc}
\hline Intervensi & $\mathbf{Z}$ & $\boldsymbol{p}$ \\
\hline Terapi Psikoedukasi & -7.086 & 0.000 \\
\hline
\end{tabular}

Berdasarkan tabel 3 terapi psikoedukasi berpengaruh sangat kuat terhadap perkembangan anak dengan $\mathrm{p}=0.000(\mathrm{p}<0.05)$

\section{PEMBAHASAN}

Hasil penelitian didapatkan sebagian besar orang tua responden bekerja sebagai ibu rumah tangga dengan latar belakang pendidikan adalah sekolah menengah. Jika dihubungkan dengan tumbuh kembang anak sebelum dilakukan pelatihan psikoedukasi ada pada kategori meragukan sebesar $51.32 \%$. Sesuai dengan hasil penelitian dikatakan bahwa ada hubungan antara Tingkat pendidikan ibu dengan perkembangan anak usia Balita (Sunanti, Fitria, 2016; Waqidil H, 2014). Perkembangan merupakan suatu perubahan yang bersifat progresif dan kontinyu pada suatu individu atau pada suatu organisme yang menuju tingkat kedewasaan atau kematangannya yang berlangsung sistematis, progresif dan berkesinambungan serta menyangkut fisik maupun psikis (Syamsu, 2007).

Untuk mengetahui tingkat perkembangan anak, maka dilakukan test perkembangan. Test perkembangan yang dilakukan menggunakan format Kuesioner Pra Skrining Perkembangan (KSSP). KPSP merupakan suatu alat atau instrumen yang digunakan untuk mendeteksi perkembangan anak apakah perkembangan anak tersebut dikatakan normal atau mengalami penyimpangan (Depkes RI, 2016). Instrumen KPSP igunakan untuk mengkategorikan perkembangan anak dengan kesimpulan sesuai (S) dengan skor 9-10, meragukan (M) dengan skor 7-8 dan penyimpangan (P) dengan skor $\leq 6$.

Menurut hasil test yang dilakukan peneliti sebelum dilakukan intervensi melalui psikoedukasi terhadap orang tua siswa didapatkan hasil bahwa sebagian besar hasil perkembangan pada kategori meragukan sebesar 51,32 \% dan penyimpangan sebesar $18,42 \%$. Hasil tes perkembangan meragukan dapat dipengaruhi banyak faktor antara lain usia anak belum sesuai dengan usia maksimal perkembangannya, anak belum mengenal pemeriksa dan anak pada kondisi yang tidak baik contohnya rewel, dan bosan. Anak-anak dengan hasil tes perkembangan meragukan, dapat dilakukan tes perkembangan ulang untuk mendapatkan hasil yang valid. Kemudian dilakukan dilakukan intervensi melalui terapi psikoedukasi. Setelah dilakukan terapi psikoedukasi, anak- anak dilakukan test perkembangan kembali. Hasil yang didapatkan ada peningkatan yang baik terhadap perkembangan anak- anak tersebut dengan hasil sebagian besar 
perkembangan sesuai (84.21\%). Meskipun demikian masih ada sebagian kecil dengan kategori meragukan (14.47\%) dan kategori penyimpangan ( $1.32 \%)$.

Psikoedukasi adalah salah satu dari berbagai elemen yang ada pada program perawatan kesehatan jiwa keluarga yaitu dengan cara memberikan informasi, edukasi yakni melalui komunikasi yang bersifat terapeutik. Program psikoedukasi merupakan suatu pendekatan terapeutik yang bersifat edukasi dan pragmatik (Stuart \& Lararia, 2005). Berdasarkan pengertian tersebut, dapat disimpulkan bahwa psikoedukasi yang dilakukan pada keluarga adalah merupakan suatu metode atau cara berdasarkan pada berbagai penemuan klinis dengan tujuan untuk melatih keluarga sehingga dapat bekerja sama secara profesional bersama-sama.

Berdasarkan penelitian Aisyah (2017) menyatakan bahwa psikoedukasi akan mempengaruhi terhadap peningkatan kemampuan pengetahuan kesiapan sekolah pada anak. Hasil penelitian menunjukkan adanya pengaruh psikoedukasi terhadap tumbuh kembang anak dengan hasil uji wilcoxon menunjukkan nilai $\mathrm{p}=0.000$. Hal ini berarti psikoedukasi yang dilakukan kepada orang tua anak terbukti sangat efektif untuk meningkatkan kualitas tumbuh kembang anak.

Keterbatasan penelitian adalah dalam pengambilan sampel masih dirasa kurang mewakii populasi sehingga perlu dilakukan penelitian lanjutan pada jumlah sampel yang lebih besar sehingga dapat mewakili suatu kesimpulan teori bahwa psikoedukasi dapat menunjang tumbuh kembang pada anak.

\section{KESIMPULAN DAN SARAN}

Peneliti menyimpulkan ada pengaruh psikoedukasi terhadap tumbuh kembang anak. Psikoedukasi yang dilakukan kepada orang tua anak terbukti sangat efektif untuk meningkatkan kualitas tumbuh kembang anak. Peneliti merekomendasikan untuk sekolah tingkat dasar atau taman kanak-kanak, perlu menfasilitasi kegiatan psikoedukasi pada orang tua dan guru dengan bekerja sama dengan psikolog atau petugas kesehatan lain guna mendukung tumbuh kembang anak.

\section{DAFTAR RUJUKAN}

Baraja, Ab. (2008). Psikologi perkembangan, tahapan-tahapan dan aspek-aspeknya dari 0 tahun sampai akhil baliq. Jakarta: Studio Pres.

Depkes RI. (2016). Stimulasi, deteksi dan intervensi dini tumbuh kembang anak di tingkat pelayanan kesehatan dasar. Jakarta: Depkes RI.

Insiyah, S. E. (2019). Parenting Psikoedukasi Dalam Mendukung Perkembangan Sosial Dan emosional Anak Usia Pra Sekolah Dikota Surakarta. Poltekkes Kemenkes Surakarta Jurusan Keperawatan, 4(2), $\quad$ 74-80. https://doi.org/https://doi.org/10.3734 1/jkg.v4i2.81

Nainggolan CRT, H. (2019). Psikoedukasi Parenting Untuk Meningkatkan Pengetahuan Ibu Dalam Mengoptimalkan 1000 HPK. Analitika, 11(2), 88-97. https://doi.org/http://dx.doi.org/analit ika.v11i1.2799 
Setiawati, F. (2006). Pendidikan Moral dan Nilai-Nilai Agama pada Anak Usia Dini: Bukan Sekedar Rutinitas. Jurnal Paradigma, 2, 41-48.

Soetjjiningsih. (2014). Tumbuh Kembang Anak. Jakarta: EGC.

Stuart \& Lararia. (2005). Buku Saku Keperawatan Jiwa (terjemahan). Jakarta: EGC.

Sunanti, Fitria, N. (2016). Karakteristik Orang Tua Dan Perkembangan Balita Usia 12-59 Bulan. Jurnal Care, 4(3), 50-61.

https://doi.org/http://dx.doi.org/10.33 366/cr.v4i3.434

Syamsu, Y. (2007). Psikologi perkembangan anak dan remaja. Bandung: PT Remaja.

Walsh, J. (2010). Psycheducation in mental health. Chicago: Lyceum Books, Inc.

Waqidil H, A. C. (2014). Hubungan Antara Tingkat Pendidikan Ibu Dengan Perkembangan Balita Usia 35 Tahun (Suatu Studi diKelurahan Kadipaten Kecamatan Bojonegoro Kabupaten Bojonegoro Tahun 2014). LPPM AKES Rajekwesi Bojonegoro, 7(2), 27-31. 